\title{
Does sex matter in reintroduction of griffon vultures Gyps fulvus?
}

\author{
M. Bosé, P. Le Gouar, C. Arthur, J. Lambourdière, J.P. Choisy, S. Henriquet, P. Lecuyer, M. Richard, \\ C. Tessier and F. Sarrazin
}

\begin{abstract}
In small populations of monogamous species sex ratio bias and sex-skewed demographic traits could lead to higher extinction probabilities than in other mating systems. Therefore a knowledge of bias in sex ratio, mortality and movement would be useful to determine the optimal strategy for sampling founders prior to reintroduction. We used molecular sexing to sex wild-hatched cohorts of two colonies (one native and one reintroduced) and four released groups of griffon vultures Gyps fulvus in France. In wild-hatched cohorts the sex ratio was not different from equilibrium whatever the year. Similarly no bias was detected in the sex
\end{abstract}

ratio of founding stocks. Recoveries, recaptures, movements and philopatry were not skewed according to sex in wild-hatched and released groups. Our study revealed that no sex bias occurred during the griffon vulture life cycle (i.e. birth, death and movement). Consequently, random sampling may be appropriate to constitute founding stock in reintroduction programmes for monomorphic vultures.

Keywords Founding stock, France, griffon vulture, Gyps fulvus, molecular sexing, mortality, reintroduction, sex ratio.

\section{Introduction}

The proportion of males and females, i.e. sex ratio, is an important factor of success for a newly founded population (Sarrazin \& Legendre, 2000). According to Fisher's (1930) and Trivers' (1972) theories on sexual selection, equilibrated sex ratio at birth is expected in monogamous species (Cockburn et al., 2002) but differential pressures on sexes could occur and lead to skewed mortality or dispersal (Gowaty, 1993; Bradshaw

\footnotetext{
M. Bosé, P. Le Gouar (Corresponding author) and F. Sarrazin Université Pierre et Marie Curie-Paris 6, UMR 5173 MNHN, CNRS, UPMC, 61 rue Buffon, 75005 Paris, France. E-mail legouar@mnhn.fr

C. Arthur Parc National des Pyrénées, Service scientifique, 59 route de Pau, 65000 Tarbes, France.

J. Lambourdière National Museum of Natural History, UMR 7138 IRD, UPMC, 43 rue Cuvier, 75231 Paris, France.

J.P. Choisy Parc naturel Régional du Vercors, 255 chemin des fusillés, 38250 Lans en Vercors, France.

S. Henriquet Ligue pour la Protection des Oiseaux délégation ProvenceAlpes-Côtes d'Azur, antenne Verdon, 5 boulevard Saint-Michel, 04120 Castellane, France.

P. Lecuyer Ligue pour la Protection des Oiseaux, antenne Grands Causses, le Bourg, 12720 Peyreleau, France.

M. Richard Université Pierre et Marie Curie-Paris 6, UMR 7625, 7 quai St. Bernard, 75005 Paris, France.

C. Tessier Association Vautours en Baronnies, Mairie, 26510 Rémuzat, France.

Received 24 July 2006. Revision requested 26 September 2006.

Accepted 14 November 2006.
}

et al., 2003). Sex ratio among sexually mature individuals is often male biased for monogamous species (BessaGomes et al., 2004). Moreover, for monogamous species, stochastic fluctuations of sex ratio in a small population could lead to higher extinction probability than in other mating systems (Legendre et al., 1999) and could affect effective population size by increasing reproductive variance among individuals (Anthony \& Blumstein, 2000). Biased sex-ratio may also cause an Allee effect, mostly because of limited mate finding (Stephens \& Sutherland, 2000; Engen et al., 2003).

Therefore, the optimal sex ratio among sexually mature individuals required to maximize reintroduction success with monogamous species is 1:1 because this ratio will maximize population growth rate (Legendre, 2004). For example, re-establishment of the monogamous white tailed sea eagle Haliaeetus albicilla in Scotland was slow because chance differences in the numbers of males and females led to a significant number of individuals failing to form pairs (Green et al., 1996). Unequivocal identification of the sex of individuals appears essential in reintroduction projects (Griffiths \& Tiwari, 1995; IUCN, 1998) but, when selecting founders, sex may be uncertain for young of most species and also for adults of monomorphic species. In such cases the strategy usually adopted is to collect individuals randomly from wild populations, hoping for a balanced sex ratio in the founding group. However, this strategy implies that sex ratio at birth and in demographic traits such as mortality and dispersal is not skewed. 
Griffon vultures Gyps fulvus, a monogamous longlived colonial scavenger, underwent a severe demographic decline in Western Europe from the end of the 19th century to the beginning of the 20th (Donázar, 1993), mainly due to human persecution and changes in agricultural practices and veterinary laws that reduced carrion availability (Terrasse, 1983). In France the griffon vulture disappeared in 1945 except in the Pyrenees. In Spain the species declined to $c$. 3,000 pairs in 1970 but increased during the 1980 s to $>18,000$ in 1999 (Del Moral \& Marti, 2001). After five reintroduction programmes three colonies were re-established in southern France by 2006. Founders were mostly weak individuals rescued by centres in Spain and the French Pyrenees or from zoos. The sex of most was unknown before release. Roselaar (1979) showed that males and females were monomorphic but analyses were carried out on only 19 skins of adult individuals. More analyses on chicks and adults are needed to confirm the sexual monomorphism of this species. Additionally, sex ratio, sexrelated mortality and movement are poorly known in populations of griffon vulture (Blanco \& Martinez, 1996). In this context, collecting weak individuals in populations to constitute founding groups for reintroduction may be a risky strategy if male and female life histories are different. There is therefore a need to study sex bias in griffon vulture life histories to improve the sampling strategy for founders.

We used a molecular sexing technique (Griffiths et al., 1998) to investigate sex patterns in native and released populations of griffon vultures. Through long-term monitoring of wild-hatched and released individuals we examined (1) whether sex ratio is balanced in both wild-hatched and released groups, (2) if there are differences in biometrical measurements between sexes, and (3) sex bias in recoveries (i.e. dead individuals collected), movements (i.e. observations of individuals out of their home range), philopatry (i.e. recruitment of an individual in its birth colony) and recaptures (i.e. rescue of weak individuals) in both groups. We expected that if, in wild-hatched populations, sex ratio is balanced and demographic traits are not sex-biased, sex ratio in released groups should also be balanced.

\section{Methods}

We studied two wild-hatched populations of griffon vulture (one native colony in the French Pyrenees in Ossau and one reintroduced population settled in the south of the Massif Central in Causses) and four released groups (Navacelles, Baronnies, Verdon, Diois; Fig. 1). After a decrease in the late 1960s the population in Ossau increased to 114 pairs in 2005. In Causses, griffon vultures were first reintroduced in the beginning

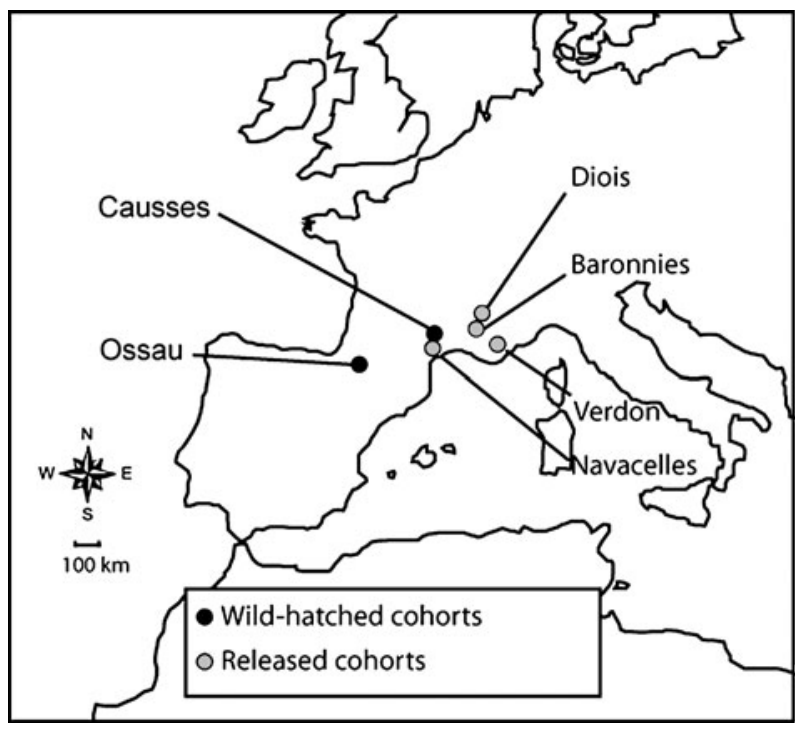

Fig. 1 Location of griffon vulture colonies studied in southern France.

of the 1980s by the Parc National des Cévennes and the Ligue pour la Protection des Oiseaux, BirdLife France (Terrasse et al., 1994, 2004). Sixty-one individuals were released from 1981 to 1986 . Since then, the population has increased continuously and reached $130-140$ pairs in 2005. Almost all birds hatched in the wild in Causses were ringed in the nest (from 1982 to 2004, $\mathrm{n}=674$ ). In Ossau, a sample of individuals has been marked each year since 1993 (from 1993 to 2004, $\mathrm{n}=432$ ).

In the locality of Navacelles, $46 \mathrm{~km}$ from Causses, 50 individuals were reintroduced from 1993 to 1997. Only one pair reproduced successfully between 1995 and 1998 and progressively all individuals left the site, which was abandoned in 1998 (Terrasse et al., 2004). In Baronnies 61 birds were released between 1996 and 2001; in 2005, 53 breeding pairs were counted. In Verdon 91 birds were released between 1999 and 2005. Seventeen pairs bred in 2005. In Diois $c$. 60 birds have been released since 1999 but most of them bred in Baronnies. All released individuals were marked with a metal ring and an identification mark in the form of a combination of three or four coloured rings or a unique engraved ring.

Individuals' tissue samples were taken during ringing from 1993 onwards (Table 1). Growing feathers of 858 wild-hatched chicks were collected and preserved in $70 \%$ ethanol. Cubitus length of 515 chicks was measured, following Elosegui (1989), by the same technician at each colony. Additionally, chicks from the Ossau population were weighed. Blood samples were collected from 179 captive adults before release and conserved in a lysis buffer (0.1 M Tris- $\mathrm{HCl}, \mathrm{pH} 8.0 ; 0.1 \mathrm{M}$ EDTA, $\mathrm{pH}$ $8.0 ; 10 \mathrm{mM} \mathrm{NaCl} ; 0.5 \% \mathrm{SDS})$. At the same time, 
Table 1 Collected samples and number of sexed individuals in all colonies (Fig. 1).

\begin{tabular}{|c|c|c|c|c|c|c|}
\hline Colony & Years & Adults & Wild-hatched chicks & Males & Females & Unsexed \\
\hline Ossau & 1993-2000, 2002 & & 305 & 147 & 147 & 11 \\
\hline Causses & $1993-2003$ & 24 & 486 & 218 & 203 & 89 \\
\hline Navacelles & 1993-1997 & 39 & 2 & 22 & 17 & 2 \\
\hline Baronnies & $1997-2004$ & 41 & 50 & 25 & 28 & 38 \\
\hline Verdon & $1999-2004$ & 29 & 15 & 23 & 12 & 9 \\
\hline Diois & 1999, 2001 & 46 & & 19 & 24 & 3 \\
\hline
\end{tabular}

biometrical measurements were taken (weight, tarsus length, bill height, head-bill length, flexed wing length; following Elosegui, 1989) of 92 of the captive birds.

\section{Molecular sexing}

We used a molecular sexing technique based on the detection of the coding chromodomain-helicase-DNAbinding gene (CHD gene; Ellegren, 1996). The CHD gene is a conservative region in most avian genomes, present in two forms linked to the two sex chromosomes, $\mathrm{Z}$ and $\mathrm{W}$, and differing in size. Both genes occur in females (the heterogametic sex in birds), whereas in males only the CHD-Z is present. DNA was extracted from 1998 to 2003 using three different methods in succession: the Chelex 100 method (Ellegren, 1994), the standard phenol/chloroform extraction (Sambrook et al., 1989) and the CTAB (Cethyl Trimethyl Ammonium Bromide) method (Kretzmann et al., 2003). In all cases we used a small clot $\left(4 \mathrm{~mm}^{2}\right)$ of thick blood or a $2 \mathrm{~mm}$ piece of the calamus. DNA extracted by the Chelex 100 method can be stored for some months at $-20^{\circ} \mathrm{C}$ while DNA extracted by the standard phenol/chloroform and the CTAB methods can be stored for some years at $-20^{\circ} \mathrm{C}$. We amplified the $\mathrm{CHD}$ gene using the primer pair P2/P8, P2 (5'-TCT GCA TCG CTA AAT CCT TT-3') + P8 (5'-CTC CCA AGG ATG AGR AAY TG-3'). Results were validated with six individuals previously sexed by laparoscopy or karyotype analysis.

\section{Statistical analysis}

We tested if sex ratio was biased in wild-hatched populations and for all released groups at Navacelles, Baronnies, Verdon and Diois with $\chi^{2}$ tests. Cohort variation in sex ratio at birth or at release was tested using a logistic regression ( $R$ v. 2.1.0; Ihaka \& Gentleman, 1996). Yates' continuity correction was applied for low number of released individuals. Biometrical measurements of wild-hatched chicks were highly age-dependent. We extracted residuals from linear regression between age and biometrical measures and we tested the effect of sex on these residuals using a gaussian general linear model (GLM). With a gaussian GLM we also tested if adults' biometrical measurements varied between sexes.

We assumed that detectability was similar in both sexes. For each sexed individual we noted if it had been found dead or not and if it moved, at least once, from the colony where it was hatched or released. We also computed recapture events of weak wild-hatched individuals. We tested if those events were sex biased using logistic regression. We computed distances of movement with geographical coordinates of departure site and control site. As individuals prospected daily within a radius up to $32 \mathrm{~km}$ (Gault, 2006) we considered only movements $>32 \mathrm{~km}$ in our analysis. Moreover, in Causses, Baronnies and Verdon, information about philopatry was available. We then tested if sex had an effect on recovery, movement and philopatry (binomial GLM). We examined effects of sex on distance of movement with a gaussian GLM. We characterized the type of movement, i.e. 'effective dispersal' if individuals bred outside their birth or release colony and 'prospecting' if individuals were occasionally seen outside their home range. We tested the effects of sex on the type of dispersal using a binomial GLM. Finally, we computed age at recovery for wild-hatched birds (RAGE), time lag from release to recovery for released individuals (RAGE2), age at first movement for wild-hatched birds (MAGE), and time lag from release to first movement (MAGE2), and tested the effect of sex on these variables.

\section{Results}

\section{Sex ratio and biometry}

Overall sex ratio of wild-hatched populations was not different from 1:1 (Causses, $\mathrm{n}=393, \chi^{2}=0.37$, $\mathrm{P}=0.54 ;$ Ossau, $\mathrm{n}=294, \chi^{2}=0.0068, \quad \mathrm{P}=0.93$; Table 1). Sex ratio was not different between cohorts in Causses $\left(\chi^{2}=3.09, \mathrm{df}=14, \mathrm{P}=0.99\right)$ or in Ossau $\left(\chi^{2}=3.002, \mathrm{df}=8, \mathrm{P}=0.93\right)$. The sex ratio of each released group was not significantly biased (Navacelles, $\mathrm{n}=37, \quad \chi^{2}=0.24, \mathrm{df}=1, \quad \mathrm{P}=0.62 ; \quad$ Baronnies, $\mathrm{n}=38, \chi^{2}=0.42, \mathrm{df}=1, \mathrm{P}=0.52$; Verdon, $\mathrm{n}=27$, $\chi^{2}=1.83, \mathrm{df}=1, \mathrm{P}=0.17$; Diois, $\mathrm{n}=43, \chi^{2}=0.58$, $\mathrm{df}=1, \mathrm{P}=0.44$; Table 1 ). Moreover, no sex bias was 
detected for each released cohort in each site (all $\mathrm{P}>0.05)$.

As expected, chick cubitus length $\left(F_{1,352}=202.8\right.$, $\mathrm{P}<0.0001)$ and chick weight $\left(F_{1,213}=123.5, \mathrm{P}<0.0001\right)$ were significantly positively correlated with age at ringing. Chick biometrical measures were not affected by sex (cubitus length, $F_{1,146}=1.65, \mathrm{P}=0.19$; weight, $\left.F_{1,146}=0.004, \mathrm{P}=0.95\right)$. On the contrary, head-bill length was significantly lower in adult males than adult females (Table 2).

\section{Recoveries, recapture, movement and philopatry}

Among the 687 sexed wild-hatched individuals, 94 were recovered, 46 were rescued and 95 moved at least once. Sex had no effect on recovery rate $\left(\mathrm{n}=687, \chi^{2}=0.15\right.$, $\mathrm{df}=1, \mathrm{P}=0.69)$, recapture rate $\left(\mathrm{n}=687, \chi^{2}=1.08\right.$, $\mathrm{df}=1, \mathrm{P}=0.29)$ or movement rate $(\mathrm{n}=687$, $\left.\chi^{2}=0.75, \mathrm{df}=1, \mathrm{P}=0.38\right)$. Of the 145 released individuals that were sexed, 13 were recovered and 61 moved at least once. We did not detect any effect of sex on recovery rate $\left(\mathrm{n}=145, \chi^{2}=3.71, \mathrm{df}=1\right.$, $\mathrm{P}=0.06)$ or movement rate $\left(\mathrm{n}=145, \chi^{2}=0.59\right.$, df $=1, \mathrm{P}=0.44)$.

Movement distances of wild-hatched birds were $54.6-3,930 \mathrm{~km}$, with $71 \%$ of movements $<500 \mathrm{~km}$. Sex had no effect on distance moved $\left(\mathrm{n}=91, F_{1,89}=2.8\right.$, $\mathrm{P}=0.09)$. Among 393 sexed individuals hatched in Causses, 36 were philopatric. Sex had no effect on philopatry $\left(\mathrm{n}=393, \chi^{2}=1.18, \mathrm{df}=1, \mathrm{P}=0.27\right)$. We did not find an effect of $\operatorname{sex}\left(\mathrm{n}=95, \chi^{2}=1.12\right.$, $\mathrm{df}=1, \mathrm{P}=0.29$ ) on the type of movement (effective dispersal vs prospecting). Movement distances of released individuals were $43-1,175.2 \mathrm{~km}$ with $95 \%$ of movements $<500 \mathrm{~km}$. As for wild-hatched populations, movement distance did not vary between sexes $(\mathrm{n}=61$, $F_{1,60}=3.6, \mathrm{P}=0.08$ ). Among 65 sexed individuals released in Baronnies and Verdon, 21 were philopatric. Sex had no effect on philopatry $\left(n=65, \chi^{2}=0.27\right.$, $\mathrm{df}=1, \mathrm{P}=0.6)$ or on the type of movement $(\mathrm{n}=61$, $\left.\mathrm{df}=1, \chi^{2}=0.44, \mathrm{P}=0.5\right)$. Sex had no effect on age at recovery (RAGE, $F_{1,94}=0.35, \mathrm{P}=0.55$; RAGE2, $F_{1,13}=2.97, \mathrm{P}=0.11$ ) or on age at first movement $\left(\mathrm{MAGE}, F_{1,101}=0.56, \mathrm{P}=0.45 ; \mathrm{MAGE} 2, F_{1,61}=1.02\right.$, $\mathrm{P}=0.31)$

\section{Discussion}

In wild-hatched groups we found a sex ratio at ringing equal to 1:1, as expected in a monomorphic species (Fisher, 1930). We suspected that sex ratio at ringing was similar to sex ratio at fledging as recoveries before fledgling were not sex-biased (10 males and seven females). Using our data on measurements we confirmed that the species is monomorphic. We found that adult females had a longer head-bill than adult males while Mundy et al. (1992) noted the opposite. However, we do not expect that this small difference would affect competitive abilities between sexes. We found no sex effect in recovery rate (frequency and age), movement rate (frequency, distance, type, age), philopatry or recapture of weak individuals in wild-hatched populations. Nevertheless, we considered recoveries to be a crude index of a combination of survival, dispersal and detectability, although any effect of sex on this index should be assessed through capture-mark-recapture (Lebreton et al., 1992) to discriminate between these processes.

Absence of sex bias in birth, mortality and dispersal could be explained by low competition between sexes and equal investment in reproduction by males and females. A skewed offspring sex ratio is expected when a difference between male and female offspring exists in their use of local resource (Clark, 1978). For griffon vultures, competition for resources does not appear to be related to sex (Bosé \& Sarrazin, 2007). In the wandering albatross, however, a long-lived, monogamous and monomorphic species, male and female parents have different survivorships due to their quality and the sex of their offspring (Weimerskirch et al., 2005). This may be due to their differential investment in parental care. However, both sexes of griffon vulture are known to invest in chick rearing (Mendelssohn \& Leshem, 1983). Sex-biased dispersal is supposed to be influenced by mating strategies (Greenwood, 1980) but direction of the bias is hard to predict when cost of inbreeding is the same for both sexes (Perrin \& Mazalov, 2000). Within the griffon vulture population around the Mediterranean no inbreeding and no differences in genetic diversity have been detected (Le Gouar et al., 2007).

Our study has therefore revealed that no sex bias occurred in any phase of the griffon vulture life cycle

Table 2 Mean biometrical measurements, with SD, for adults caught during the study. Measurements that differed significantly between adult males and females are indicated in bold.

\begin{tabular}{llllll}
\hline & Weight $(\mathrm{g})$ & Tarsus length $(\mathrm{mm})$ & Head-bill length $(\mathrm{mm})$ & Bill height $(\mathrm{mm})$ & Flexed wing length $(\mathrm{mm})$ \\
\hline Males & $8,279.31 \pm 186(\mathrm{n}=29)$ & $128.8 \pm 4.9(\mathrm{n}=18)$ & $\mathbf{1 4 5 . 4} \pm \mathbf{1 . 1 6}(\mathbf{n}=\mathbf{1 6})$ & $36 \pm 0.9(\mathrm{n}=12)$ & $710.1 \pm 6.2(\mathrm{n}=24)$ \\
Females & $8,912 \pm 201(\mathrm{n}=25)$ & $122.9 \pm 4.3(\mathrm{n}=14)$ & $\mathbf{1 5 0 . 5} \pm \mathbf{1 . 2 4}(\mathbf{n}=\mathbf{1 4})$ & $34.9 \pm 1.02(\mathrm{n}=11)$ & $707.2 \pm 6.6(\mathrm{n}=21)$ \\
Sex effect testing & $F_{1,54}=0.02 \mathrm{P}=0.89$ & $F_{1,42}=1.06 \mathrm{P}=0.32$ & $F_{1,33}=\mathbf{6 . 8 6} \mathbf{P}=\mathbf{0 . 0 1 9}$ & $F_{1,27}=0.14 \mathrm{P}=0.70$ & $F_{1,44}=2.94 \mathrm{P}=0.11$ \\
\hline
\end{tabular}


(i.e. birth, death, movement, philopatry and recapture). Consequently, sampling of rescued birds would not lead to sex-biased founding stocks. In the colonies in France the sex ratio of all released stocks was balanced and sex patterns in recoveries, movement and philopatry were not disturbed by reintroduction. As a result, no mating limitation and high reproductive success are expected in these founding populations because of their monogamous mating system (Legendre, 2004). However, the relationship between the growth of reintroduced populations and sex-ratio depends on their mating system. For instance, Komers \& Curman (2000) found that in polygamous ungulate species population growth was positively influenced by a male biased sex ratio.

To conclude, we detected no sex bias in demographic parameters of griffon vultures hatched in the wild or in released populations, confirming the effectiveness of founder sampling to form sex-balanced founding stock in monogamous and sexually monomorphic species. However, the genetic and behavioural consequences of this strategy also need to be monitored.

\section{Acknowledgements}

This study results from collaboration with various organizations in charge of the griffon vulture reintroduction and conservation programmes: Parc National des Cévennes, Parc National des Pyrénées, Parc naturel régional du Vercors, LPO Grands Causses, LPO PACA, Association 'Vautours en Baronnies', Association 'Vautours en Haute-Provence', and Office National des Forêts. We owe special thanks to J.L. Pinna, D. Peyrusqué, J.M. Tabard and O. Lannès, who collected tissue samples. We thank J.M. Pericard for sexing griffon vultures using laparoscopy. We also thank J. Shykoff for support and advice, and B. Gautschi and S. Nadot for technical support. Financial support came from the Ministère de l'Ecologie et du Developpement Durable, Institut d'Ecologie Fondamentale et Appliquée (IFR101-CNRS) and from a Swiss National Science Foundation Grant 31-49477.96 to Dr Jürg Paul Müller and Professor B. Schmid.

\section{References}

Anthony, L.L. \& Blumstein, D.T. (2000) Integrating behaviour into wildlife conservation: the multiple ways that behaviour can reduce $\mathrm{N}_{\mathrm{e}}$. Biological Conservation, 95, 303-315.

Bessa-Gomes, C., Legendre, S. \& Clobert, J. (2004) Allee effects, mating systems and the extinction risk in populations with two sexes. Ecology Letters, 7, 802-812.

Blanco, G. \& Martinez, F. (1996) Sex difference in breeding age of griffon vulture (Gyps fulvus). The Auk, 113, 247-248.
Bosé, M. \& Sarrazin, F. (2007) Competitive behaviour and feeding rate in a reintroduced population of griffon vulture Gyps fulvus. Ibis, 149, 490-501.

Bradshaw, C.J.A., Harcourt, R.G. \& Lloyd, S.D. (2003) Malebiased sex ratios in New Zealand fur seal pups relative to environmental variation. Behavioural Ecology and Sociobiology, 53, 297-307.

Clark, A.B. (1978) Sex ratio and local resource competition in a prosimian primate. Science, 208, 1157-1159.

Cockburn, A., Legge, S. \& Double, M.C. (2002) Sex ratios in birds and mammals: can the hypotheses be disentangled? In Sex Ratios: Concepts and Research Methods (ed. I.C.W. Hardy), pp. 267-286. Cambridge University Press, Cambridge, UK.

Del Moral, J.C. \& Marti, R. (2001) El buitre Leonado en la Península Ibérica, III Censo Nacional y I Censo Ibérico coordinado, 1999. SEO/BirdLife, Madrid, Spain.

Donázar, J.A. (1993) Los Buitres Ibericos. Biologia y conservation. J.M. Reyero, Madrid, Spain.

Ellegren, H. (1994) Genomic DNA from museum bird feathers. In Ancient DNA (eds B. Hermann \& S. Hummel), pp. 211-217. Springer, New York, USA.

Ellegren, H. (1996) First gene on the avian W chromosome (CHD) provides a tag for universal sexing of non-ratite birds. Proceedings of the Royal Society of London: Series B, 263, 1635-1641.

Elosegui, I. (1989) Vautour fauve (Gyps fulvus), Gypaete barbu (Gypaetus barbatus), Percnoptère d'Egypte (Neophron percnopetrus): Synthèse bibliographique et recherches. Acta Biologica Montana 3, Série document de travail. Centre de Biologie des Ecosystèmes d'Altitude, Pau, France.

Engen, S., Lande, R. \& Sæther, B.E. (2003) Demographic stochasticity and Allee effect in populations with two sexes. Ecology, 84, 2378-2386.

Fisher, R.A. (1930) The General Theory of Natural Selection. Clarendon Press, Oxford, UK.

Gault, A. (2006) Prospection alimentaire et impact de la distribution spatiale et temporelle des resources trophiques chez le Vautour fauve (Gyps fulvus). PhD thesis, University of Pierre et Marie Curie, Paris, France.

Gowaty, P.A. (1993) Differential dispersal, local resource competition, and sex ratio variation in birds. American Naturalist, 141, 263-280.

Green, R.E., Pienkowski, M.W. \& Love, J.A. (1996) Long-term viability of the re-introduced population of the white-tailed eagle Halixetus albicilla in Scotland. Journal of Applied Ecology, 33, 357-368.

Greenwood, P.J. (1980) Mating systems, philopatry and dispersal in birds and mammals. Animal Behaviour, 28, 1140-1162.

Griffiths, R., Double, M.C., Orr, K. \& Dawson, R.J.G. (1998) A DNA test to sex most birds. Molecular Ecology, 7, 1071-1075.

Griffiths, R. \& Tiwari, B. (1995) Sex of the last wild Spix's macaw. Nature, 375, 454.

Ihaka, R. \& Gentleman, R. (1996) R: a language for data analysis and graphics. Journal of Computational and Graphical Statistics, 5, 299-314.

IUCN (1998) Guidelines for Re-introductions. IUCN/SSC Re-introduction Specialist Group, Gland, Switzerland.

Komer, P. \& Curman, P. (2000) The effect of demographic characteristics on the success of ungulate re-introductions. Biological Conservation, 93, 187-193.

Kretzmann, M.B., Capote, N., Gautschi, B., Godoy, J.A., Donázar, J.A. \& Negro, J.J. (2003) Genetically distinct island 
populations of the Egyptian vulture (Nephron percnopterus). Conservation Genetics, 4, 697-706.

Lebreton, J.D., Burnham, K.P., Clobert, J. \& Anderson, D.R. (1992) Modelling survival and testing biological hypotheses using marked animals: a unified approach with case studies. Ecological Monographs, 62, 67-118.

Legendre, S. (2004) Age structure, mating system and population viability. In Evolutionary Conservation Biology (eds R. Ferrière, U. Dieckmann \& D. Couvet), pp. 41-58. Cambridge University Press, Cambridge, UK.

Legendre, S., Clobert, J., Møller, A.P. \& Sorci, G. (1999) Demographic stochasticity and social mating system in the process of extinction of small populations: the case of passerines introduced to New Zealand. American Naturalist, 153, 449-463.

Le Gouar, P., Rigal, F., Boisselier-Dubayle, M.C., Sarrazin, F., Arthur, C., Choisy, J.P., Hatzofe, O., Henriquet, S., Lecuyer, P., Tessier, C., Susic, G. \& Samadi, S. (2007) Genetic variation in a network of natural and reintroduced populations of griffon vulture (Gyps fulvus) in Europe. Conservation Genetics, in press (DOI 10.1007/s10592-007-9347-6).

Mendelssohn, H. \& Leshem, Y. (1983) Observations on reproduction and growth of Old World Vultures. In Vulture Biology and Management (eds S.R. Wilbur \& J.A. Jackson), pp. 214-241. University of California Press, Berkeley, USA.

Mundy, P., Butchart, D., Ledger, J. \& Piper, S. (1992) The Vultures of Africa. Academic Press, London, UK.

Perrin, N. \& Mazalov, V. (2000) Local competition, inbreeding, and the evolution of sex-biased dispersal. American Naturalist, 155, 116-127.

Roselaar, C.S. (1979) The Birds of the Western Palearctic, Vol. 2 (eds S. Cramp \& R.E.L. Simmons), pp. 58-95. Oxford University Press, Oxford, UK.

Sambrook, J., Fritsch, E.F. \& Maniatis, T. (1989) Molecular Cloning: A Laboratory Manual, 2nd edition. Cold Spring Harbor Laboratory Press, New York, USA.

Sarrazin, F. \& Legendre, S. (2000) Demographic approach to releasing adults versus young in reintroductions. Conservation Biology, 14, 488-500.

Stephens, P.A. \& Sutherland, W. (2000) Vertebrate mating systems, Allee effects and conservation. In Vertebrate Mating
Systems (eds M. Apollonio, M. Festa-Bianchet \& D. Mainardi), pp. 186-213. World Scientific Publishing, London, UK.

Terrasse, M. (1983) The status of vultures in France. In Vulture Biology and Management (eds S.R. Wilbur \& J.A. Jackson), pp. 81-85. University of California Press, Berkeley, USA.

Terrasse, M., Bagnolini, C., Bonnet, J., Pinna, J.L. \& Sarrazin, F. (1994) Reintroduction of the griffon vulture Gyps fulvus in the Massif Central, France. In Raptor Conservation Today. Proceedings of the IV World Conference on Birds of Prey and Owls (eds B.U. Meyburg \& R.D. Chancellor), pp. 479-491. Pica Press/WWGBP, Berlin, Germany.

Terrasse, M., Sarrazin, F., Choisy, J.P., Clémente, C., Henriquet, S., Lecuyer, P., Pinna, J.L. \& Tessier, C. (2004) A success story: the reintroduction of Eurasian griffon Gyps fulvus and black Aegypius monachus vultures to France. In Raptor Worldwide. Proceedings of the VI World Conference on Birds of Prey and Owls (eds R.D. Chancellor \& B.U. Meyburg), pp. 127-145. WWGBP/MME, Budapest, Hungary.

Trivers, R.L. (1972) Parental investment and sexual selection. In Sexual Selection and the Descent of Man (ed. B. Campbell), pp. 136-179. Aldine, Chicago, USA.

Weimerskirch, H., Lallemand, J. \& Martin, J. (2005) Population sex-ratio variation in a monogamous long-lived bird, the wandering albatross. Journal of Animal Ecology, 74, 285-291.

\section{Biographical sketches}

Michela Bosé studies social feeding behaviour and intraspecific competition in griffon vultures. Pascaline Le Gouar is studying the impact of breeding habitat selection on the success of reintroduced populations through demographic, genetic and behavioural analyses and spatially explicit modelling. Christian Arthur, Jean Pierre Choisy, Sylvain Henriquet, Philippe Lecuyer and Christian Tessier monitor and manage griffon vulture colonies on a daily basis to improve their conservation. Josie Lambourdière and Muriel Richard work to improve molecular techniques on various species. François Sarrazin's main interests are the short- and long-term viability of restored populations. 